\title{
A Study on Genetic Variability for Yield and its Attributes in Sweet Basil (Ocimum basilicum L.)
}

\author{
M. Pavan Gowda, A.V.D. Dorajeerao*, M. Madhavi and D.R. Salomi Suneetha
}

Dr. YSR Horticultural University, Venkataramannagudem, Tadepalligudem - 534 101, Andhra Pradesh, India

*Corresponding author

\begin{abstract}
A B S T R A C T
An experiment was carried out in Randomized Block design with thirteen genotypes of sweet basil each replicated thrice. Assessing variability is essential to identify the most

\begin{tabular}{|l|}
\hline Key w or d s \\
Sweet basil, \\
Variability, GCV, \\
PCV, Heritability, \\
GAM \\
\hline Article Info \\
\hline Accepted: \\
24 May 2019 \\
Available Online: \\
10 June 2019 \\
\hline
\end{tabular}
important traits in sweet basil genotypes which help in crop improvement programme. The population genotypic coefficients of variation (GCV), phenotypic coefficients of variation (PCV), broad sense heritability $\left(h_{b}^{2}\right)$, genetic advance and genetic advance as per cent of mean (GAM) for twenty four characters were analysed to record the degree of variability of sweet basil genotypes. The estimates of phenotypic variance were higher than those of genotypic variance for all the traits, thereby indicating the influence of environment in the expression of these traits. High estimates of GCV and PCV were recorded for total fresh weight of plant $(35.74 \% ; 39.50 \%)$, fresh weight of leaves $(30.66 \% ; 36.80 \%)$ and spikes $(40.67 \% ; 45.26 \%)$ per plant, oil yield from leaves $(45.91 \%$; $49.55 \%)$ and spikes $(58.28 \%$; $61.19 \%)$ per plant. High heritability estimates in conjunction with high GAM was observed for total fresh weight of plant $(81.87 \% ; 66.61 \%)$, fresh weight of leaves $(69.42 \%$; $52.63 \%)$ and spikes $(80.78 \%$; $75.31 \%)$ per plant and oil yield from leaves $(85.87 \%$; $87.64 \%)$ and spikes $(90.54 \%$; $114.13 \%)$ per plant. Besides, seed yield per plant also exhibited GCV, PCV, heritability and GAM in high range $(52.75 \%, 61.28 \%, 74.09 \%$ and 93.52\%).
\end{abstract}

\section{Introduction}

The Ocimum genus belongs to the family Lamiaceae. There are about 50 to 150 species in this genus belonging to herbs and shrubs distributed over tropical regions of Asia, Africa and Central and South America (Bailey, 1924). Ocimum is the most important aromatic medicinal plants since the time of old civilization. Being a polymorphic group of economically useful herbs, it forms a rich source of many naturally occurring essential oils and aromatic chemicals (Khosla et al., 2000). Sweet basil is used in folk medicine due to its stimulant, carminative and antispasmodic properties (Marotti et al., 1996). It is also having febrifuge and antimalarial properties. Thus, infusion of the plant is used for gouty joints, cephalalgia and gargle for foul breath. Relief in irrigation for throat, earache and ring worm is also well known properties of basil extracts. (Farooqi and Sreeramu, 2004) 
The area under cultivation and average yield of basil in India is low. One of the reasons for less growing and low yield is lack of genotypes suited to a particular region. In basil, the selection is based on herbage yield, oil yield and oil quality along with their component characters which would prove very useful. Evaluation of the genotypes is required across different agro-climatic regions to know their performance in terms of yield and its attributing characters. Based on this, promising genotypes can be identified and they can be used further in breeding programme. Genetic variability is an important factor for any heritable improvement. Knowledge of genetic variability, its nature and degree is useful for selecting desirable genotypes from a germplasm (Ojo et al., 2012). The value of germplasm collection depends not only on the number of accessions, but also on the genetic variability present in those accessions and magnitude of heritable portion of variation (Singh and Narayanan, 1993). Wide genetic variability that exists in the available germplasm provides ample scope for further improvement. Keeping this in view, the present investigation was done to know the variability among different characters in sweet basil.

\section{Materials and Methods}

An investigation entitled "Performance of basil (Ocimum spp.) genotypes in Godavari zone of Andhra Pradesh" was carried out during kharif season, 2018-2019 at $\mathrm{COH}$, Venkataramannagudem, West Godavari district. The location falls under Agroclimatic zone-10, humid, East Coast Plain and Hills (Krishna-Godavari zone) with an average annual rainfall of $900 \mathrm{~mm}$ at an altitude of $34 \mathrm{~m}$ (112 feet) above mean sea level. The geo-graphical situation is $16^{\circ} 63^{\prime}$ 120 " N latitude and $81^{\circ} 27^{\prime} 568^{\prime \prime}$ E longitude. It experiences hot humid summer and mild winter. A total of thirteen sweet basil genotypes viz., IC110267, IC201233, IC281185, IC326732, IC326771, IC336833, IC338959, IC344681, IC369247, IC381552, IC395778, IC469923 and IC469938 sourced from NBPGR, New Delhi were taken for study. The experiment was laid out in RBD with three replications. The observations were recorded on various growth, yield and quality parameters. Essential oil percentage was recorded by using Clevenger apparatus (Clevenger, 1928) and expressed on dry weight basis from this oil yield was also computed by taking 100 gram fresh sample for analysis.

The data obtained in respect to all the characters viz., plant height $(\mathrm{cm})$, plant spread $\left(\mathrm{cm}^{2}\right)$, number of primary and secondary branches, number of leaves leaf area per plant $\left(\mathrm{cm}^{2}\right)$, total fresh and dry weight of plant $(\mathrm{g})$, fresh weight of leaves and spikes per plant (g), leaf and spike dry matter content (\%), dry weight of leaves and spikes per plant (g), days to $50 \%$ flowering, number of spikes per plant, spike length $(\mathrm{cm})$, per cent of oil from leaves and spikes (DWB), Oil yield from leaves and spikes per plant $(\mathrm{g})$, number of seeds per spike, test weight of seeds ( $\mathrm{g}$ ) and seed yield per plant (g) was subjected to the following statistical analysis. The data were analyzed by the methods outlined by Panse and Sukhatme (1985) using the mean values of five random plants in each replication from all genotypes to find out the significance of genotypes effect. Genotypic and phenotypic coefficients of variation were estimated according to Burton and Devane (1953), Categorization of PCV and GCV was based on the ranges of variation as reported by Sivasubramanian and Menon (1973), Heritability in broad sense was estimated as per the formulae suggested by Allard (1960). Genetic advance was estimated as per the formula proposed by Lush (1940) and Johnson et al., (1955). Genetic advance as per cent over mean was 
obtained by dividing genetic advance with general mean of the character. The ranges of $h^{2}{ }_{b}$ and GAM were categorized as suggested by Johnson et al., (1955).

\section{Results and Discussion}

The population genotypic coefficients of variation (GCV), phenotypic coefficients of variation $(\mathrm{PCV})$, heritability, genetic advance and genetic advance as per cent of mean (GAM) for important quantitative characters were analysed to record the degree of variability of sweet basil genotypes and presented in Table 2.

The estimates of phenotypic variance were higher than those of genotypic variance for all the traits (Table 1), thereby indicating the influence of environment in the expression of these traits. Since the estimates of variances solely do not provide means to assess the nature of genetic variability, phenotypic and genotypic coefficients of variation were also computed. The PCV was significantly higher than GCV for most of the traits under study confirming the environmental intervention.

\section{Genotypic coefficient of variation (\%)}

In this experiment, GCV was in high range for the traits plant height $(22.93 \%)$, plant spread $(34.05 \%)$, number of secondary branches per plant (28.68\%), number of leaves $(29.51 \%)$, leaf area per plant $(29.31 \%)$, total fresh weight of plant $(35.74 \%)$, total dry weight of plant $(35.80 \%)$, fresh weight of leaves per plant $(30.66 \%)$, leaf dry matter content (25.18\%), dry weight of leaves per plant $(27.83 \%)$, number of spikes per plant (43.12\%), spike length (32.39\%), fresh weight of spikes per plant $(40.67 \%)$, dry weight of spikes per plant $(36.81 \%)$, per cent oil from leaf $(28.05 \%)$, oil yield from leaves per plant (45.91\%), per cent oil from spike $(31.33 \%)$, oil yield from spikes per plant $(58.28 \%)$, number of seeds per spike $(22.46 \%)$ and seed yield per plant $(52.75 \%)$.

The values were in moderate range for number of primary branches per plant $(18.46 \%)$ and spike dry matter content $(16.77 \%)$ whereas the traits days to $50 \%$ flowering (10.89\%) and test weight of seeds $(8.68 \%)$ were found to show GCV in low range.

\section{Phenotypic coefficient of variation (\%)}

PCV was in the high range for the traits viz., plant height (22.05\%), plant spread (34.64\%), number of primary branches per plant (26.24\%), number of secondary branches per plant $(31.30 \%)$, number of leaves $(32.41 \%)$, leaf area per plant (37.03\%), total fresh weight of plant $(39.50 \%)$, total dry weight of plant $(40.16 \%)$, fresh weight of leaves per plant $(36.80 \%)$, leaf dry matter content $(28.17 \%)$, dry weight of leaves per plant $(36.29 \%)$, number of spikes per plant (52.30\%), spike length (35.08\%), fresh weight of spikes per plant $(45.26 \%)$, spike dry matter content $(21.61 \%)$, dry weight of spikes per plant $(44.82 \%)$, per cent oil from leaf $(30.61 \%)$, oil yield from leaves per plant (49.55\%), per cent oil from spike $(33.90 \%)$, oil yield from spikes per plant (61.19\%), number of seeds per spike $(22.87 \%)$ and seed yield per plant $(61.28 \%)$. Days to $50 \%$ flowering (10.90\%) and test weight of seeds $(9.69 \%)$ exhibited PCV in low range.

The estimates of PCV and GCV were high for plant height, plant spread, number of secondary branches per plant, number of leaves per plant, leaf area per plant, total fresh weight of plant, total dry weight of plant, fresh weight of leaves per plant, leaf dry matter content, dry weight of leaves per plant, number of spikes per plant, spike length, fresh weight of spikes per plant, dry weight of spikes per plant, per cent oil from leaf, oil 
yield from leaves from plant, per cent oil from spike, oil yield from spikes from plant, number of seeds per spike and seed yield per plant, thus indicating the existence of more variability for these traits among the genotypes. Similar results were found by Pushpangadan et al., (1979) for fresh weight of plant and oil yield, Morales et al., (1993) for plant height, fresh and dry weights of plant, days to $50 \%$ flowering, leaf area per plant and oil yield, Ibrahim et al., (2013) for plant height and dry weight in basil. In mint Singh et al., (1999) and Singh et al., (2000) found similar high estimates for plant height, oil content and oil yield in leaf and herb.

Number of primary branches per plant and spike dry matter content showed moderate GCV and high PCV. The estimates of PCV and GCV were distant to each other for these characters which indicated that number of primary branches and spike dry matter content were much influenced by environmental factors. These outcomes are in accordance with the findings of Singh and Kumar (2010) and Smita and Kishori (2018) for number of branches in basil.

Low estimates of PCV and GCV recorded for days to $50 \%$ flowering and test weight of seeds indicated the presence of less genetic variability as a result of which less scope for selection.Low PCV and GCV for these attributes is in conformity with conclusions given by Anyaoha (2013) for test weight of seeds and Smita and Kishori (2018) for days to $50 \%$ flowering.

\section{Heritability in broad sense $\left(h_{b}^{2}\right)$}

Heritability estimates give a measure of transmission of characters from one generation to the next and consistency in the performance of progeny in succeeding generations. The estimate depends mainly on the magnitude of heritable portion of variation
(Singh and Narayanan, 1993). The estimates of heritability in broad sense (\%) for important quantitative characters were computed and presented in Table 2. The broad sense heritability estimates provides information on relative magnitude of genetic and environmental variation on performance of genotypes.

High heritability estimates were observed for most of the important quantitative traits studied viz. plant height (83.8\%), plant spread (96.63\%), number of secondary branches per plant $(83.95 \%)$, number of leaves $(82.90 \%)$, leaf area per plant (62.63\%), total fresh weight of plant $(81.87 \%)$, total dry weight of plant $(79.49 \%)$, fresh weight of leaves per plant $(69.42 \%)$, leaf dry matter content (79.93\%), days to $50 \%$ flowering $(99.80 \%)$, number of spikes per plant $(67.98 \%)$, spike length $(85.25 \%)$, fresh weight of spikes per plant $(80.78 \%)$, spike dry matter content $(60.21 \%)$, dry weight of spikes per plant $(67.45 \%)$, per cent oil from leaf $(83.95 \%)$, oil yield from leaves per plant $(85.87 \%)$, per cent oil from spike $(85.42 \%)$, oil yield from spikes per plant $(90.54 \%)$, number of seeds per spike $(96.40 \%)$, test weight of seeds $(80.19 \%)$ and seed yield per plant (74.09\%).Number of primary branches per plant $(49.49 \%)$ and dry weight of leaves per plant $(58.79 \%)$ exhibited moderate heritability.

\section{Genetic advance as percentage of mean}

Genetic advance denotes the improvement in mean genotypic values of selected individuals over base population and thus helps breeder to select the progenies in the earlier generation itself (Singh and Narayanan, 1993).

Genetic advance (percentage of mean) was observed to be high for most of the important quantitative characters studied viz. plant height (43.25\%), plant spread $(68.96 \%)$, number of primary branches per plant 
(26.75\%), number of secondary branches per plant $(54.12 \%)$, number of leaves $(55.34 \%)$, leaf area per plant $(47.78 \%)$, total fresh weight of plant $(66.61 \%)$, total dry weight of plant $(65.76 \%)$, fresh weight of leaves per plant $(52.63 \%)$, leaf dry matter content (46.38\%), dry weight of leaves per plant (43.95\%), days to $50 \%$ flowering $(22.41 \%)$, number of spikes per plant $(73.24 \%)$, spike length $(61.61 \%)$, fresh weight of spikes per plant $(75.31 \%)$, spike dry matter content (26.81\%), dry weight of spikes per plant $(62.27 \%)$, per cent oil from leaf $(52.94 \%)$, oil yield from leaves per plant (87.64\%), per cent oil from spike (59.65\%), oil yield from spikes per plant (114.13\%), number of seeds per spike (45.42\%), and seed yield per plant $(93.52 \%)$ whereas, test weight of seeds $(16.01 \%)$ showed moderate genetic advance (percentage of mean).

Table.1 Mean, Range, Genotypic, Phenotypic and Environment variance among different characters in sweet basil (Ocicum basilicum L.) genotypes

\begin{tabular}{|c|c|c|c|c|c|}
\hline Character & Mean & Range & GV & PV & EV \\
\hline Plant height (cm) & 74.29 & $47.22-112.67$ & 290.27 & 346.39 & 56.12 \\
\hline Plant spread $\left(\mathrm{cm}^{2}\right)$ & 1689.72 & $826.00-2806.89$ & 331129.19 & 342693.7 & 11564.51 \\
\hline Number of primary branches & 15.21 & $11.85-21.15$ & 7.88 & 15.95 & 8.65 \\
\hline Number of secondary branches & 71.59 & $48.67-116.22$ & 421.46 & 502.05 & 80.59 \\
\hline Number of leaves & 1416.02 & $507.70-2151.48$ & 174564.98 & 210561.33 & 35996.35 \\
\hline Leaf area per plant $\left(\mathrm{cm}^{2}\right)$ & 9485.86 & $5256.21-1974.72$ & 7729525.74 & 1241748.15 & 4612222 \\
\hline Total fresh weight of plant (g) & 564.6 & $306.96-1046.96$ & 40717.94 & 49737.78 & 9019.85 \\
\hline Total dry weight of plant (g) & 131.97 & $71.31-245.92$ & 2232.32 & 3808.16 & 575.84 \\
\hline $\begin{array}{l}\text { Fresh weight of leaves per plant } \\
\text { (g) }\end{array}$ & 217.04 & $105.56-343.33$ & 4429.23 & 6380.03 & 1950.8 \\
\hline Leaf dry matter content (\%) & 14.95 & $11.40-25.33$ & 14.17 & 17.33 & 3.56 \\
\hline $\begin{array}{l}\text { Dry weight of leaves per plant } \\
\text { (g) }\end{array}$ & 31.14 & $18.13-52.68$ & 75.09 & 127.72 & 52.63 \\
\hline Days to $50 \%$ flowering & 65.93 & $56.46-80.39$ & 51.53 & 51.63 & 0.1 \\
\hline Number of spikes per plant & 147.19 & $59.00-285.63$ & 4028.84 & 5926.76 & 1897.92 \\
\hline Spike length $(\mathrm{cm})$ & 22.07 & $13.67-36.78$ & 51.1 & 59.95 & 8.84 \\
\hline $\begin{array}{l}\text { Fresh weight of spikes per plant } \\
\text { (g) }\end{array}$ & 177.68 & $56.19-295.33$ & 5222.86 & 6465.74 & 1242.87 \\
\hline Spike dry matter content (\%) & 23.43 & $19.77-33.67$ & 15.44 & 25.64 & 10.2 \\
\hline $\begin{array}{l}\text { Dry weight of spikes per plant } \\
\text { (g) }\end{array}$ & 40.38 & $18.93-63.74$ & 220.91 & 327.52 & 106.6 \\
\hline $\begin{array}{l}\text { Per cent of oil from leaves } \\
\text { (DWB) }\end{array}$ & 3.05 & $1.33-4.44$ & 0.73 & 0.87 & 0.14 \\
\hline $\begin{array}{l}\text { Oil yield from leaves per plant } \\
\text { (g) }\end{array}$ & 0.95 & $.28-1.83$ & 0.19 & 0.22 & 0.03 \\
\hline $\begin{array}{l}\text { Per cent of oil from spikes } \\
\text { (DWB) }\end{array}$ & 2.36 & $0.89-3.42$ & 0.55 & 0.64 & 0.09 \\
\hline $\begin{array}{l}\text { Oil yield from spikes per plant } \\
\text { (g) }\end{array}$ & 1.02 & $0.17-2.05$ & 0.35 & 0.39 & 0.04 \\
\hline Number of seeds per spike & 173.1 & $126.33-278.33$ & 1511.21 & 1567.65 & 56.44 \\
\hline Test weight of seeds (g) & 10.5 & 1.24-1.82 & 0.02 & 0.02 & 0 \\
\hline Seed yield per plant (g) & 38.7 & $15.92-81.48$ & 416.62 & 562.34 & 145.72 \\
\hline
\end{tabular}


Table.2 Genotypic and phenotypic coefficients of variation, heritability in broad sense, genetic advance and genetic advance as per cent mean in sweet basil (Ocicum basilicum L.) genotypes

\begin{tabular}{|c|c|c|c|c|c|}
\hline Character & GCV & PCV & $\mathrm{H} 2$ & GA & GAM \\
\hline Plant height (cm) & 22.93 & 22.05 & 83.8 & 32.13 & 43.25 \\
\hline Plant spread $\left(\mathrm{cm}^{2}\right)$ & 34.05 & 34.64 & 96.63 & 1165.23 & 68.96 \\
\hline Number of primary branches & 18.46 & 26.24 & 49.49 & 4.07 & 26.75 \\
\hline Number of secondary branches & 28.68 & 31.3 & 83.95 & 38.75 & 54.12 \\
\hline Number of leaves & 29.51 & 32.41 & 82.9 & 783.67 & 55.34 \\
\hline Leaf area per plant $\left(\mathrm{cm}^{2}\right)$ & 29.31 & 37.03 & 62.63 & 4532.44 & 47.78 \\
\hline Total fresh weight of plant (g) & 35.74 & 39.5 & 81.87 & 376.11 & 66.61 \\
\hline Total dry weight of plant (g) & 35.8 & 40.16 & 79.49 & 86.78 & 65.76 \\
\hline Fresh weight of leaves per plant (g) & 30.66 & 36.8 & 69.42 & 114.23 & 52.63 \\
\hline Leaf dry matter content $(\%)$ & 25.18 & 28.17 & 79.93 & 6.93 & 46.38 \\
\hline Dry weight of leaves per plant (g) & 27.83 & 36.29 & 58.79 & 13.69 & 43.95 \\
\hline Days to $50 \%$ flowering & 10.89 & 10.9 & 99.8 & 14.77 & 22.41 \\
\hline Number of spikes per plant & 43.12 & 52.3 & 67.98 & 107.8 & 73.24 \\
\hline Spike length $(\mathrm{cm})$ & 32.39 & 35.08 & 85.25 & 13.6 & 61.61 \\
\hline Fresh weight of spikes per plant (g) & 40.67 & 45.26 & 80.78 & 133.8 & 75.31 \\
\hline Spike dry matter content $(\%)$ & 16.77 & 21.61 & 60.21 & 6.28 & 26.81 \\
\hline Dry weight of spikes per plant (g) & 36.81 & 44.82 & 67.45 & 25.15 & 62.27 \\
\hline Per cent of oil from leaves (DWB) & 28.05 & 30.61 & 83.95 & 1.61 & 52.94 \\
\hline Oil yield from leaves per plant (g) & 45.91 & 49.55 & 85.87 & 0.83 & 87.64 \\
\hline Per cent of oil from spikes (DWB) & 31.33 & 33.9 & 85.42 & 1.41 & 59.65 \\
\hline Oil yield from spikes per plant (g) & 58.28 & 61.19 & 90.54 & 1.16 & 114.13 \\
\hline Number of seeds per spike & 22.46 & 22.87 & 96.4 & 78.63 & 45.42 \\
\hline Test weight of seeds (g) & 8.68 & 9.69 & 80.19 & 0.24 & 16.01 \\
\hline Seed yield per plant (g) & 52.75 & 61.28 & 74.09 & 36.19 & 93.52 \\
\hline
\end{tabular}

Table.3 Fresh weight, Oil yield and seed yield per plant in sweet basil (Ocimum basilicum L.) genotypes

\begin{tabular}{|r|c|c|c|c|c|c|c|c|}
\hline \multirow{2}{*}{ Genotype } & \multicolumn{9}{|c|}{ Fresh weight per plant $(\mathrm{g})$} & \multicolumn{3}{c|}{ Oil yield per plant $(\mathrm{g})$} & \multirow{2}{*}{$\begin{array}{c}\text { Seed yield per plant } \\
(\mathrm{g})\end{array}$} \\
\cline { 2 - 9 } & Leaves & Spikes & Stem & Total & Leaves & Spikes & Total & 81.48 \\
\hline IC110267 & 343.33 & 264.59 & 439.04 & 1046.96 & 1.83 & 1.80 & 3.63 & 18.14 \\
\hline IC201233 & 164.33 & 105.26 & 187.19 & 449.11 & 0.61 & 0.47 & 1.08 & 20.35 \\
\hline IC281185 & 169.22 & 100.74 & 123.96 & 393.93 & 0.70 & 0.40 & 1.11 & 22.70 \\
\hline IC326732 & 315.00 & 208.78 & 219.30 & 726.07 & 1.40 & 1.17 & 2.57 & 28.68 \\
\hline IC326771 & 149.17 & 149.41 & 22.89 & 359.63 & 0.78 & 0.75 & 1.52 & 32.92 \\
\hline IC336833 & 223.00 & 153.70 & 124.93 & 501.63 & 0.97 & 0.80 & 1.76 & 37.82 \\
\hline IC338959 & 211.78 & 178.89 & 219.48 & 610.15 & 0.90 & 0.93 & 1.83 & 15.92 \\
\hline IC344681 & 105.56 & 56.19 & 101.61 & 306.96 & 0.50 & 0.17 & 0.67 & 22.04 \\
\hline IC369247 & 156.67 & 92.41 & 50.67 & 307.41 & 0.60 & 0.32 & 0.92 & 70.98 \\
\hline IC381552 & 187.33 & 256.67 & 312.81 & 675.04 & 0.28 & 1.67 & 1.95 & 55.70 \\
\hline IC395778 & 241.56 & 233.70 & 61.30 & 610.00 & 1.58 & 1.45 & 3.03 & 36.02 \\
\hline IC469923 & 256.56 & 214.19 & 163.26 & 634.00 & 1.17 & 1.26 & 2.43 & 60.33 \\
\hline IC469938 & 298.00 & 295.33 & 182.07 & 718.96 & 1.04 & 2.05 & 3.09 & $\mathbf{3 8 . 7 0}$ \\
\hline Mean & $\mathbf{2 1 7 . 7 8}$ & $\mathbf{1 7 7 . 6 8}$ & $\mathbf{1 6 9 . 8 8}$ & $\mathbf{5 6 4 . 6 0}$ & $\mathbf{0 . 9 5}$ & $\mathbf{1 . 0 2}$ & $\mathbf{1 . 9 7}$ & 6.97 \\
\hline S Em \pm & 25.50 & 20.35 & 32.26 & 54.83 & 0.10 & 0.11 & 0.18 & 20.34 \\
\hline CD $(\mathbf{0 . 0 5})$ & $\mathbf{7 4 . 4 3}$ & 59.41 & 94.17 & 160.05 & 0.30 & 0.35 & 0.52 & \\
\hline
\end{tabular}


High heritability in conjunction with high GAM was observed for plant height, plant spread, number of secondary branches per plant, number of leaves per plant, leaf area per plant, total fresh weight of plant, total dry weight of plant, fresh weight of leaves per plant, leaf dry matter content, days to $50 \%$ flowering, number of spikes per plant, spike length, fresh weight of spikes per plant, spike dry matter content, dry weight of spikes per plant, per cent oil from leaf, oil yield from leaves from plant, per cent oil from spike, oil yield from spikes from plant, number of seeds per spike and seed yield per plant, thus indicating the preponderance of additive gene action governing the inheritance of these characters and offers the best possibility of improvement through simple selection procedures. Hence, direct selection based on these traits in genetically diverse material could be effective for desired improvement. Similar results were found by Pushpangadan et al., (1979) for fresh weight of plant and oil yield in basil, Sharma and Tyagi (1991) for herb yield and oil content in mint, Verma et al., (1998) for herb and oil yield in basil, Singh et al., (1999) and Singh et al., (2000) for plant height, oil content and oil yield in leaf and herb in mint, Singh and Coudhary (2008) for seed yield per plant in Ajowan, Smita and Kishori (2018) for spike length in basil.

Moderate heritability coupled with high genetic advance (percentage mean) was observed for number of primary branches per plant and dry weight of leaves per plant, which might be due to positive environmental influence bringing more prominence to the additive gene action for these characters. These results were in conformity with conclusions given by Singh and Kumar (2010) and Smita and Kishori (2018).

On the contrary, the high heritability as worked out for test weight of seeds which might be as a result of additive gene action; was moderated due to negative impact of environment as reckoned by the moderate genetic advance as per cent of mean and therefore selection based on this trait may not be of great advantage. These outcomes are in accordance with the findings of Singh and Coudhary (2008).

The estimates of phenotypic variance were higher than those of genotypic variance for all the traits indicating the influence of environment in their expression. In sweet basil, high heritability coupled with high GAM was observed for plant height, plant spread, number of secondary branches per plant, number of leaves per plant, leaf area per plant, total fresh weight of plant, total dry weight of plant, fresh weight of leaves per plant, leaf dry matter content, days to $50 \%$ flowering, number of spikes per plant, spike length, fresh weight of spikes per plant, spike dry matter content, dry weight of spikes per plant, per cent oil from leaf, oil yield from leaves from plant, per cent oil from spike, oil yield from spikes from plant, number of seeds per spike and seed yield per plant, thus indicating the preponderance of additive gene action governing the inheritance of these characters offering the best possibility of improvement through simple selection procedures. On the basis of the study of accessions IC110267 recorded highest herb (total fresh weight of plant), oil and seed yield per plant, (herb - 1046g; oil - $3.63 \mathrm{~g}$; seed $81.48 \mathrm{~g}$ ) (Table 3).

\section{References}

Allard, R.W. 1960. Principles of plant breeding. John Wiley \& Sons, New York. USA.

Anyaoha, C.O. 2013. Agro-morphological variability of Ocimum gratissimum L. and other accessions of Basil in southern Nigeria. The African Journal 
of Plant science and Biotechnology. 7(1): 89-92.

Bailey, L.H., 1924. Manual of Cultivated plants. Macmillan Co. New York. 101-03.

Burton, G.W. and Devane, E.H. 1953. Estimating the heritability in tall fescue (Festuca arundinancea) from replicated clonal material. Agronomy Journal. 45: 478-81.

Clevenger, J,F., 1928. Apparatus for determination of essential oil. Journal of American Pharmacists Association. 17: 346-49.

Ibrahim, M.M, Aboud, K.A. and Al-Ansary, A.M.F. 2013. Genetic variability among three sweet basil (Ocimum basilicum L.) varieties as revealed by morphological traits and RAPD markers. World Applied Sciences Journal. 24 (11): 1411

Johnson, H.W., Robinson, H.F. and Comstock , R.E. 1955. Estimates of geneticand environmental variability in soyabean. Agronomy Journal. 47: 314-18.

Khosla, M.K, Bhasin, M. and Thappa, R.K. 2000. Essential oil composition of some improved species of Ocimum. Indian Perfumer. 44(3): 175-81.

Lush, J.L. 1940. Heritability of quantitative characters in farm animals. Proceedings of $85^{\text {th }}$ Congress on Genetics, Heriditas (Supplement). pp. 356-75.

Marotti, M, Piccaglia, R. and Giovanelli, E. 1996. Differences in essential oil composition of basil (Ocimum basilicum L.) Italian cultivars related to morphological characteristics. Journal of Agricultural and Food Chemistry. 44 (12): 3926-29.

Morales, M.R, Charles, D.J. and Simon, J.E. 1993. New aromatic lemon basil germplasm. In: New Crops. J. Janick and J.E. Simon (Eds.), Wiley, New York. 632-35.
Ojo, O,D, Adebayo, O,S, Olaleye, O. and Orkpeh, U. 2012. Basil (Ocimum basilicum) genetic variability and viral disease assessment in Nigeria. Asian Journal of Agricultural Sciences. 4(1): 1-4.

Panse, V.G. and Sukhatme, P.V. 1985. Statistical Methods for Agriculture Workers. Indian Council of Agriculture Research Publications. New Delhi, pp. 152-74.

Pushpangadan, P, Sobti, S.N. and Thappa, R.K. 1979. Genetical improvement and physio-chemical evaluation of a citral type strain of Ocimum americanum L. Indian Perfumer. 23 (1): 21-24.

Sharma, S and Tyagi, B.R. 1991. Character correlation, path coefficient and heritability analyses of essential oil and quality components in Japanese mint. Journal of Genetics and Breeding. 45(4): 257-62.

Singh, J.M, Sharma, R, Sood, M, Srivastava, L.J. and Chand, R. 1999. Genetic variation and heritability studies for some oil yield contributing characters in spearmint (Mentha spicata L.). Indian Perfumer. 43(3): 122-125.

Singh, N. and Kumar, D. 2010. Variability, Heritability and genetic advance in Tulsi (Ocimum sanctum L.). Asian Sciences. 5(2): 89-92.

Singh, P. and Narayana, S.S. 1993. Biometrical Techniques in Plant Breeding. KalyaniPublishers, New Delhi.

Singh, P. and Narayana, S.S. 1993. Biometrical Techniques in Plant Breeding. Kalyani Publishers. New Delhi.

Singh, S.P, Tiwari, R.K. and Dubey, T. 2000. Studies on selection parameters in Mentha arvensis. Journal of Medicinal and Aromatic Plant Science. 22: 44346. 
Singh and Choudhary, P.S. 2008. Evaluation of ajowain (Trachyspermum ammi L.) genotypes suitable for semi-arid regions. Journal of Spices and Aromatic Crops. 17(2): 167-71.

Sivasubramanian, S. and Menon, M. 1973. Heterosis and inbreeding depression in rice. Madras Agricultural Journal. 60: 1139.

Smita, S. and Kishori, R.L. 2018. Estimation of genetic variability, heritability and genetic advance for essential oil yield and related traits in genus Ocimum. Advances in Crop Science and Technology. 6(2): 1-6.

Verma, P.K, Gupta, S.N, Khabiruddin, M. and Sharma, G.D. 1998a. Genetic variability parameters for herb and oil yield in different Ocimum species. Indian Perfumer. 42 (1): 36-38.

Verma, R.S, Bisht, P.S, Padalia, R.C, Saikia, D. and Chauhan, A. 2011. Chemical composition and antibacterial activity of essential oil from two Ocimum spp. grown in subtropical India during spring-summer cropping season. Journal of Traditional Medicine. 6: 211-17.

Farooqi, A.A. and Sreeramu, B.S. 2004. Cultivation of Medicinal and Aromatic crops. Universities Press, revised edition. pp 429-36

\section{How to cite this article:}

Pavan Gowda, M. A.V.D. Dorajeerao, M. Madhavi and. Salomi Suneetha, D.R 2019. A Study on Genetic Variability for Yield and its Attributes in Sweet Basil (Ocimum basilicum L.). Int.J.Curr.Microbiol.App.Sci. 8(06): 2995-3003. doi: https://doi.org/10.20546/ijcmas.2019.806.357 